\title{
Konsep Kewirausahaan dalam Tafsir Al-Azhar dan Relevansinya dengan Materi Mata Kuliah Kewirausahaan
}

\author{
${ }^{1}$ Indah Kurniati, ${ }^{2}$ Isnanita Noviya Andriyani, ${ }^{3}$ Azis \\ 123STAI Masjid Syuhada Yogyakarta \\ Azisabdullah2018@gmail.com
}

\begin{abstract}
Abstrak: Penelitian ini untuk mengkaji tentang kosnep kewirausahan dalam tafsir AlAzhar dan mengkaji relevansi dengan kurikulum mata kuliah kewirausahan di perguruan tinggi. Jenis penelitian ini kajian pustaka dengan metode pengumpulan datanya menggunakan dokumentasi dengan metode analisis isi. Hasilnya penelitian bahwa konsep dasar kewirausahaan adalah dasar bekerja, tujuan bekerja adalah ibadah, syaratsyarat bekerja dan bekerja tidak melupakan akherat. Nilai-nilai kewirausahaan dalam tafsir al-Azhar adalah nilai kreatif, jujur, inovatif, tanggung jawab, realistis dan kerja sama. Adanya relevansi antara konsep kewirausahaan dalam tafsir al-Azhar dengan materi mata kuliah kewirausahaan. Intinya mengajak pelaku usaha kembali kepada dasar al-Quran dan as-Sunnah sebagai pedoman dalam menjalankan berbagai bentuk usahanya di dunia. Kemudian dalam proses usahanya perlu dukungan nilai-nilai kewirausahaan yang tertanam dalam dirinya.
\end{abstract}

Kata kunci: Kewirausahaan, Tafsir, Materi Kuliah, Pedoman

Abstract: This research is to examine the concept of entrepreneurship in Al-Azhar's interpretation and to examine the relevance of the curriculum of entrepreneurship courses in universities. This type of research is literature review with data collection methods using documentation with content analysis methods. The results showed that the basic concept of entrepreneurship is the basis of work, the purpose of work is worship, the conditions for work and work do not forget the hereafter. Entrepreneurial values in al-Azhar's interpretation are creative, honest, innovative, responsible, realistic and cooperative values. There is a relevance between the concept of entrepreneurship in al-Azhar's interpretation and the entrepreneurship subject matter. The point is to invite business actors to return to the basics of the Koran and as-Sunnah as a guide in carrying out various forms of business in the world. Then in the business process, it is necessary to support entrepreneurial values that are embedded in him.

Keywords: Entrepreneurship, Interpretation, Course Material, Guidelines

\section{PENDAHULUAN}

Kewirausahaan dalam ajaran Islam merupakan dimensi sosial yang dikelompokkan dalam bidang mu'amalah yang berkaitan hubungan manusia dengan Allah dan hubungan manusia dengan manusia. Di kehidupan modern proses perkembangan dunia usaha dan bertransaksi mulai bergeser nilai dan tujuannya. ${ }^{1}$ Oleh karena itu perlu ada solusi yang tepat untuk menghadapi perkembangan kewirausahaan, salah satunya kembali kepada tuntunan ajaran Islam sebagaimana

${ }^{1}$ Bahri, Kewirausahaan Islam: Penerapan Konsep Berwirausaha dan Bertransaksi Syariah dengan Metode Dimensi Vertikal (Hablumminallah) dan Dimensi Horizontal(Hablumminannas), Maro Jurnal Ekonomi Syariah dan Bisnis,Vol. 1. No.2 November 2018, 67. 
telah dipraktekkan oleh Rasulullah Saw. Pribadi Rasulullah Saw telah menjadi bukti nyata bahwa manusia adalah makhluk istimewa yang telah diciptakan Allah Swt. Muhammad Saw telah melakukan transaksi-transaksi perdagangan secara jujur, adil dan tidak pernah membuat pelanggannya mengeluh dan kecewa. ${ }^{2}$ Para entrepreneur yang menyandarkan diri dan upaya yang maksimal hanya kepada Allah, harus tetap mempertahankan keyakinannya tersebut secara istiqomah dan konsisten. Dalam berwirausaha jiwa yang istiqomah dan konsisten akan melahirkan optimisme bahwa usaha yang dijalankan bakal sukses, kesediaan mengambil risiko dan tidak gampang menyerah menghadapi tantangan. ${ }^{3}$

Jiwa kewirausahaan akan mengantarkan manusia untuk meraih kesuksesan. Juga mendorong semangat manusia ketika mengalami kegagalan, dapat mengobati jiwa ketika terjatuh dalam kegagalan dan kepahitan-kepahitan menjalani usahanya. Dalam dunia pendidikan, jiwa kewirausahaan menjadi tolak ukur keberhasilan mahasiswa di masa depan. Seperti data sebagai berikut Rasio wirausaha di Indonesia masih sebesar 1,56 persen atau sekitar 3.707.205 orang. 32 Dr. Andri Soemitra, MA. manyatakan semestinya harus ada minimal ada 4,75 juta wirausaha. Padahal, tingkat kelulusan strata I mencapai 300 ribu orang dan SLTA mencapai 2,5 juta orang per tahun. Minat berwirausaha masih rendah. Untuk lulusan Perguruan Tinggi, yang berminat menjadi wirausaha hanya 6,4 persen, sementara untuk tingkat SLTA jumlahnya hanya 22,4 persen. ${ }^{4}$

Penelitian di Harvard University Amerika Serikat misalnya, ternyata kesuksesan tidak ditentukan semata-mata oleh pengetahuan dan kemampuan skill, tapi oleh kemampuan mengelola diri dan orang lain. Penelitian mengungkapkan, kesuksesan $20 \%$ oleh hard skill dan sisanya $80 \%$ oleh soft skill. ${ }^{5}$ Hal tersebut sesuai yang ditegaskan dalam agama Islam itu agama dinamis. Artinya agama yang menekankan produktifitas. Agama Islam adalah agama yang mendorong manusia untuk senantiasa aktif. Prinsip-prinsip tersebut telah dipraktekkan oleh Rasulullah saw dalam aspek kemerdekaan, kebebasan dan kepercayaan diri dalam pengalaman yang menyenangkan, di bawah asuhan Halimah, Abdul Muthalib dan Abu Thalib.

Hasil penelitian pendidikan kewirausahaan di tingkat pendidikan dasar dan menengah yang diteliti oleh Pusat Penelitian Kebijakan dan Inovasi Pendidikan Kemendiknas (27 Mei 2010), 6 bahwa pendidikan kewirausahaan mampu

${ }^{2}$ Afzalurrahman, Muhammad sebagai Seorang Pedagang, (Jakarta: Media Dakwah, 1997), 1.

${ }^{3}$ Andri Soemitra. Kewirausahaan Berbasis Syariah, (Medan: CV. Manhaji dengan Fakultas Syariah dan Hukum UIN Sumatera Utara, 2015), 43.

${ }^{4}$ Andri Soemitra. Kewirausahaan Berbasis Syariah.........31-32..

${ }^{5}$ Agus Wibowo, Op. Cit., h. 17-18.

${ }^{6}$ Komaruddin Hidayat, Psikologi Kebahagiaan, (Jakarta : Noura Books, 2015), 144-145. 
menghasilkan hasil yang positif sebagai profesi wirausaha. Bukti hasil penelitian ditemukan baik tingkat sekolah dasar, menengah pertama maupun menengah atas, bahwa peserta didik di sekolah tersebut, menghasilkan sikap positif terhadap profesi wirausaha.

\section{TEORI KEWIRAUSAHAAN}

\section{Kewirausahaan}

Istilah kewirausahaan sudah dikenal orang dalam sejarah ilmu ekonomi sebagai ilmu pengetahuan sejak tahun $1755 .{ }^{7}$ Seorang Perancis bernama Richard Cantillon, ahli ekonomi Perancis keturunan Irlandia sebagi orang pertama yang memakai konsep entrepreneur dan entrepreneurship. Cantillon menekankan konsep entrepreneurship memberikan peran yang besar dalam ilmu ekonomi. Cantillon menyatakan seorang entrepreneur adalah yang akan membayar harga untuk produk tertentu, kemudian menjual dengan proses jual beli sesuai kesepakatan antara penjual dan pembeli, mendayagunakan sumber-sumber daya dan selalu siap menerima resiko apapun. Pada abad 19 dan permulaan abad ke 20 para entrepreneur tidak ada perbedaan antara kelompok manajer dan pengusaha dalam sudut pandang ekonomi. Kemudian pada abad ke 20 ada ide baru bahwa seorang entrepreneur sebagai inovator artinya orang yang menemukan produk-produk baru yang penuh dengan inovasi. ${ }^{8}$ Sedang Ricard T. Elly dan Ralph H. Hess, menegaskan bahwa seorang entrepreneur mempunyai kemampuan mengorganisir dan mengoperasikan sebuah perusahaan untuk mencapai tujuan yang telah ditentukan. 9

Entrepreneur disebut dengan kewirausahaan, menurut ejaan bahasa Indonesia, kewirausahaan terdiri dari beberapa suku kata, yaitu ke-wirausahaan, istilah wirausaha adalah seseorang yang mempunyai kemampuan dalam melihat peluang dan menciptakan sebuah organisasi, dengan memanfaatkan peluang-peluang yang ada untuk memulai menjalankan bisnis yang baru. Atau kemampuan untuk menangkap setiap peluang usaha yang ada, kemudian dimanfaatkanya sebagai lahan usaha atau bisnis dan seluruh waktunya selalu dicurahkan untuk menemukan peluang-peluang bisnisnya. Dunia wirausaha merupakan jalan usaha seseorang yang dijalankan untuk memperoleh keuntungan yang besar dan juga kemungkinan memperoleh kerugian yang tidak terduga, berdasarkan skala kualitas seseorang wirausaha, maka oleh

${ }^{7}$ J. Winardi, Entrepreneur dan Entrepreneurship, (Jakarta: Prenadamedia Group, 2003), 1.

8. Winardi, Entrepreneur dan Entrepreneurship......, 1-2.

${ }^{9}$ J. Winardi, Entrepreneur dan Entrepreneurship......, 3. 
karena itu seorang usahawan dalam melangkah dunia bisnisnya harus didukung dengan pribadi-pribadi tangguh, pantang menyerah, percaya diri, kemampuan mental-emosional dan kemampuan membaca peluang-peluang dalam usahanya. ${ }^{10}$ Kewirausahaan bukan merupakan ilmu ajaib yang mendatangkan uang dalam sekejap, melainkan sebuah ilmu, seni dan keterampilan untuk mengelola semua keterbatasan sumber daya, informasi, dan dana yang ada guna mempertahankan hidup, mencari nafkah, atau meraih posisi puncak dalam karir. ${ }^{11}$

Pendapat Joseph Schumpeter yang dikutip oleh Winardi, mennegaskan seorang ekonom yang telah melakukan penelitian tentang entrepreneur dan entrepreneurship: ditegaskan bahwa fungsi para entrepreneur adalah mengubah pola produksi sesuai dengan teori yang ditemukan dari penemuanpenemuan baru, dijadikan sebagai solusi perkembangan teknologikal untuk memproduksi sebuah komoditi baru, atau memproduksi komoditi yang lama dengan cara inovasi yang baru, selalu membuka sumber suplai bahan-bahan baru, atau sebagai cara penyaluran inovasi baru atau mengorganisasi sebuah industri baru. ${ }^{12}$

Perlu diperhatikan dengan cermat bahwa para ahli ekonomi dunia Eropa, telah dapat mempengaruhi konsep entrepreneurship abad ke-20, perhatian selalu tertuju proses interaksi bisnis pada model-model ekonomi makro sebagai fokus perhatiannya. ${ }^{13}$ Seorang entrepreneur sebagai pelaku perubahan (change agent) selalu mempunyai kemampuan untuk mentransformasikan sumber-sumber daya yang dimiliki menjadi barang-barang dan jasa-jasa yang berharga untuk usahanya, dan selalu dapat menciptakan situasi dan keadaan yang dapat menyebabkan timbulnya pertumbuhan dunia industri. ${ }^{14}$ Seorang entrepreneur sebagai seorang individu yang selalu siap menerima resiko dan menyiapkan langkah-langkah yang tepat untuk mengejar peluang-peluang dalam situasi dan keadaan tertentu, sedangkan pihak lain tidak dapat melihatnya dan merasakannya atau menganggap sebagai problem-problem dunia usahanya yang akan menjadi ancaman yang membahayakan. ${ }^{15}$ Entrepreneurship disebut juga sebagai perilaku dinamis, menerima berbagai

${ }^{31}$ Eko Agus Alfianto, t.t, Kewirausahaan : Sebuah Kajian Pengabdian Kepada Masyarakat. Dalam jurnal Universitas Yudharta Pasuruan, 2-3.

${ }^{11}$ Suryana, Kewirausahaan, Pedoman Praktis Kiat dan Proses Menuju Sukses, (Jakarta: Salemba Empat, 2009), 2.

${ }^{12}$ J. Winardi, Entrepreneur dan Entrepreneurship......,3

13. Winardi, Entrepreneur dan Entrepreneurship......, 4-5.

${ }^{14}$. Winardi, Entrepreneur dan Entrepreneurship......, 5.

15J. Winardi, Entrepreneur dan Entrepreneurship......, 16. 
resiko yang ada, kreatif dan selalu berorientasi pada pertumbuhan. Entrepereurship tidak dapat dihasilkan dari proses sifat genetic saja, akan tetapi merupakan kemampuan dan ketrampilan yang harus dipelajari dan kembangkan dalam dunia usahanya. ${ }^{16}$

Agus Wibowo menegaskan arti entrepreneurship adalah kewirausahaan, sedang entrepreneur adalah wirausaha yang melakukan usaha kongkrit. Konsep entrepreneurship, mengandung berbagai keragaman definisi, karena kewirausahaan termasuk dalam bidang ilmu sosial yang bersifat dinamis dan fleksibel, dan selalu mengalami perubahan-perubahan seiring dengan perkembangan ilmu yang dimiliknya. ${ }^{17}$ Pendapat Pinchot dalam buku Agus Wibowo, kewirausahaan adalah kemampuan untuk menginternalisasikan bakat, rekayasa, dan peluang yang ada. Sementara entrepreneur adalah orang yang berani mengambil resiko, inovatif, kreatif, pantang menyerah dan mampu menyiasati peluang secara tepat. 18

Menurut Kemendiknas yang dikutip oleh Agus Wibowo, entrepreneurship merupakan proses perkembangan dan pertumbuhan sikap, jiwa dan kemampuan menciptakan produk baru yang bernilai dan berguna, baik untuk dirinya maupun orang lain. Artinya entrepreneurship merupakan proses aktualisasi mental dan jiwa yang kreatif, aktif, berdaya guna, inovatif, berkarya, bersahaja, dan berusaha meningkatkan pendapatan dan keuntungan dalam usahanya. Sedang entrepreneur/wirausaha adalah pelaku usaha yang memiliki ketrampilan memanfaatkan berbagai peluang yang ada, dalam rangka mengembangkan usahanya, dengan tujuan untuk meningkatkan pendapatan dan tarap kehidupannya. ${ }^{19}$

Azyumardi Azra menekankan bahwa peningkatan SDM melalui pendidikan sebagai satu cara yang paling efektif untuk mengentaskan kemiskinan, walaupun memerlukan waktu yang relatif lama dan panjang. Sebagaimana yang diharapkan oleh Kemendiknas. ${ }^{20}$ Lebih-lebih jika pendidikan kemandirian sudah ditanamkan sejak dini, sebagaimana nilai-nilai sikap kemandirian, artinya sikap dan perilaku yang tidak mudah tergantung pada orang lain dalam menyelesaikan tugas-tugas. ${ }^{21}$

\footnotetext{
16. Winardi, Entrepreneur dan Entrepreneurship......, 16 dan 20.

17 Agus Wibowo. 2011. Pendidikan Kewirausahaan,..... 24.

${ }^{18}$ Agus Wibowo. 2011. Pendidikan Kewirausahaan,..... 24-25.

${ }^{19}$ Agus Wibowo. 2011. Pendidikan Kewirausahaan,..... 24-25.

${ }^{20}$ Azyumardi Azra, Pendidikan Islam Tradisi dan Modernisasi, (Jakarta: Logos, 1999), 54.

${ }^{21}$ Suharyanta, Administrasi Pendidikan Islam, (Yogyakarta: Idea Press, 2012), 34-37.
} 
Usaha pendidikan yang diterapkan bertujuan untuk mengembangkan jiwa kemandirian dalam usaha akan menjadi sesuatu yang sangat penting. Hal ini untuk dijadikan strategi dalam dunia usaha, sebab ada factor-faktor dan gejalagejala yang negatif yang dapat menjadi hambatan. Gejala-gejala negatif yang ada sebagai berikut:

a. Ketergantungan sikap disiplin selalu terkontrol dari eksternal dan tidak karena niat secara ikhlas.

b. Sikap yang tidak selalu peduli terhadap lingkungan hidup, baik lingkungan fisik maupun sosial.

Sikap hidup manusia yang tidak didukung oleh pemahaman dan kompromi dengan lingkungannya, akan berakibat mengorbankan prinsip-prinsipnya. Di satu sisi sikap kecenderungan untuk menghormati orang lain, semakin dilandasi dengan niat yang baik, bukan karena hakikat kemanusiaan, tapi karena ada pertimbangan atribut-atribut pihak lain. ${ }^{22}$

\section{Kewirausahaan di Lembaga Pendidikan}

Proses penginternalisasian kewirausahaan di dunia pendidikan, baik kepada peserta didik di tingkat dasar, menengah maupun perguruan tinggi, agar memiliki karakter dan atau perilaku wirausaha yang tangguh, dan diharapkan menjadi sumber daya manusia yang tangguh serta mampu menciptakan lapangan pekerjaan, minimal bagi diri sendiri. ${ }^{23}$

Terlepas dari kekurangan dalam praktek pendidikan di Indonesia, apabila dilihat dari standar nasional pendidikan yang menjadi acuan pengembangan kurikulum, pendidikan kewirausahaan sebenarnya termasuk dalam materi yang harus diajarkan dan dikuasai serta direalisasikan oleh anak didik dalam kehidupan sehari-hari. ${ }^{24}$

Kewirausahaan dalam lembaga pendidikan itu harus diperluas dalam jangkauan dan cakupannya sebagai sebuah fenomena yang baik. Pendidikan sebagai aktifitas adalah upaya dirancang untuk membantu seseorang atau kelompok dalam mengembangkan pandangan dan sikap hidup, serta keterampilan hidup baik yang bersifat fisik maupun non fisik. Sedang pendidikan sebagai fenomena adalah berkembangnya suatu pandangan hidup, sikap hidup dan keterampilan hidup. Kemudian perilaku pandangan hidup,

${ }^{22}$ Mohammad Ali \& Mohammad Asori, Psikologi Remaja Perkembangan Peserta Didik, (Jakarta: PT. Bumi Aksara, 2014), 108-109.

${ }^{23}$ Mohammad Ali \& Mohammad Asori, Psikologi Remaja......., 29.

${ }^{24}$ Mohammad Ali \& Mohammad Asori, Psikologi Remaja......., 29. 
sikap hidup dan keterampilan hidup harus selalu bernafaskan nilai-nilai Islam yang bersumber dari al-Qur'an dan As-Sunnah. ${ }^{25}$

Menurut Kemendiknas, kewirausahaan di tingkat dasar atau sekolah bertujuan untuk membentuk manusia secara utuh, yaitu selain sebagai insan yang memiliki karakter, juga memiliki pemahaman dan ketrampilan sebagai seorang wirausaha. Kewirausahaan dapat diterapkan dalam kurikulum yang dikembangkan dan dintegrasikan dalam setiap mata pelajaran. Selain itu juga dapat diimplementasikan secara terpadu dengan kegiatan-kegiatan pendidikan di sekolah, seperti kegiatan intra-kurikuler dan ekstrakurikuler. ${ }^{26}$

Pendapat lain bahwa program kewirausahaan selalu menggarap aspek kewirausahaan sebagai pembekalan kompetensi peserta didik. ${ }^{27}$ Adapun proses realisasinya melalui setiap mata pelajaran yang diajarkan dan dikaitkan dengan kehidupan. Sehingga proses pembelajaran yang berwawasan kewirausahaan tidak hanya pada pengetahuan saja, tapi pengamalan. Selanjutnya dalam pelaksanaan ini, segenap komponen sekolah seperti pengawas sekolah, kepala, untuk mewujudkan proses tersebut.. ${ }^{28}$ Secata tegas dapat dikatakan bahwa masalah kewirausahaan sangat urgen untuk dikembangkan dalam berbagai aspek, khususnya dalam dunia pendidikan. Hal ini akan memberikan arahan dan bekal bagi generasi penerus untuk mengembangkan potensi kecerdasan akal dan jiwa dengan dikuatkan dasardasar professional.

\section{METODE PENELITIAN}

Jenis penelitian ini adalah studi kepustakaan (library research), ${ }^{29}$ dengan menggunakan pendekatan antropologis. Pendekatan ini merupakan cara pandang melihat sebuah gejala atau fenomena yang tidak lepas dari perilaku dan tata cara kehidupan serta proses perjalanan hidup manusia yang berkaitan dengan budaya ${ }^{30}$ Melalui pendekatan ini penulis akan mengkaji tentang konsep dasar dan nilai-nilai kewirausahaan dalam tafsir Al-Azhar karya Hamka dan relevansinya dengan materi kuliah kewirausahaan. ${ }^{31}$ Sumber data primer dalam penelitian ini adalah kitab Tafsir

\footnotetext{
${ }^{25}$ Suti'ah Muhaimin dkk, Paradigma Pendidikan Islam, (Bandung: PT Remaja Rosdakarya, 2002), 37-38.

${ }^{26}$ Suti'ah Muhaimin dkk, Paradigma Pendidikan Islam....., 45-46.

${ }^{27}$ Muhammad Sa'roni, "Mendidiki \& Melatih Entrepreneur Muda, (Yogyakarta: Ar-Ruzz Media, 2012), 45

${ }^{28}$ Agus Wibowo. 2011. Pendidikan Kewirausahaan,..... 46.

${ }^{29}$ Sugiyono, 2015. Cara Mudah Menyusun Skripsi, Tesis dan Disertasi, (Bandung : Alfabeta), 22.

30 Tim Penyusun, 2018. Pedoman Penulisan Skripsi, (Yogyakarta: STAIMS Press), 26.

${ }^{31}$ Ibid., hlm. 132.
} 
Al-Azhar karya Hamka. Teknik pengumpulan data dalam penelitian yaitu dokumentasi. Dokumentasi adalah cara untuk memperoleh data-data dalam bentuk tulisan, catatan, dan benda-benda lainnya. ${ }^{32}$ Suharsimi Arikunto menegaskan cara mencari data yang berbentuk catatan, prestasi, agenda dan sebagainya. ${ }^{33}$ Metode dokumentasi digunakan untuk mengkaji tentang biografi Hamka, konsep dasar dan nilai-nilai kewirausahaan dalam tafsir al-Azhar karya Hamka dan relevansinya dengan materi mata kuliah kewirausahaan di STAI Masjid Syuhada Yogyakarta.

Analisis data adalah proses mencari dan menyusun secara sistematis data yang diperoleh dari pengumpulan data. Analisis data yang digunakan adalah content analysis yaitu suatu metode yang teknik penelitiannya dilakukan dengan membuat inferensi secara kontekstual. ${ }^{34}$

\section{PEMBAHASAN}

Ayat-ayat yang berkaitan dengan konsep dasar dan nilai-nilai kewirausahaan di bawah ini merupakan petunjuk dan motivasi untuk melakukan aktivitas yang menghasilkan untuk kehidupan, dalam bentuk berwirausaha dan bentuk kegiatan yang lain, agar orang dapat memenuhi kebutuhan pokok sehari-hari. Konsep kewirausahaan dalam tafsir al-Azhar karya Hamka sebagai berikut:

\section{Konsep Dasar Kewirausahaan.}

Dasar kewirausahaan merupakan konsep dasar yang terdapat dalam tafsir alAzhar yang dijadikan dasar atau pondasi dalam melaksanakan kewirausahaan, yang sesuai dengan tuntunan al-Quran dan as-Sunnah, sebagaimana telah dipraktekkan oleh Rasulullah Saw. Kemudian konsep dasar yang dimaksud adalah:

a) Dasar Bekerja.

Proses penghidupan manusia dalam dunia kewirausahaan seperti perniagaan, jual beli, cinta harta, dan cinta dunia, tidak akan bernilai bila tidak didasarkan cinta kepada Allah sebagai sumber kehidupan manusia. Hal ini ditegaskan dalam al-Qur'an surat at-Taubah ayat 24.

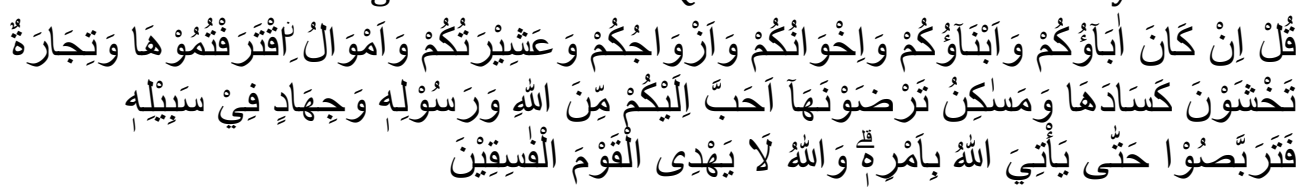

Artinya:"Katakanlah: Jika bapak-bapak kamu dan anak-anak kamu, saudara-saudara kamu dan istri-istri kamu dan kaum keluarga kamu dan harta benda yang kamu dapati, dan perniagaan yang kamu takuti

32 Koentjaraningrat, Metode Penelitian, (Jakarta : Gramedia, 1983), 63.

33 Suharsimi Arikunto, Prosedur Penelitian, (Jakarta: Rineka Cipta, 2006), 236.

34 Sugiyono, Op. Cit., 232-233. 
akan kerugiannya dan tempat-tempat kediaman yang kamu sukai. Lebih kamu sukai daripada Allah dan Rasul-Nya serta berjihad pada jalan-Nya. Maka tunggulah sehingga Allah memberikan keputusan-Nya. Dan Allah tidak memberi petunjuk kepada orang-orang yang fasik". 35

Cinta kepada manusia sebagai ayah, anak, saudara, istri dan keluarga, kalau tidak diikatkan karena cinta kepada Allah, akan menyebabkan orang tenggelam dalam kehidupan yang sia-sia dan tidak berarti apa-apa, serta dapat menjadi bakhil. ${ }^{36}$ Bahkan Allah memberi julukan orang fasik yaitu tidak memedulikan seruan kebenaran Allah, dan memperturutkan kehendak hati sendiri, maka akan turun kekayaan jiwa dan ruhnya. ${ }^{37}$

Solusinya adalah dengan mempertebal iman kepada Allah, maka kasih cinta dalam jiwa kepada delapan (bapak/ibu, anak, saudara, suami istri, keluarga, perniagaan, kediaman dan nikmat Allah), niscaya akan berjalan dengan sewajarnya. Allah tidak melarang manusia mencintai dunia, sebab telah menjadi naluri manusia yang terdapat dalam jiwanya. 38

b) Tujuan Bekerja adalah Ibadah.

Tujuan bekerja menurut perintah Allah adalah bekerja maksimal dan mencari penghasilan dengan memanfaatkan kemampuan dan juga sumber daya, merupakan ibadah. Hal ini dijelaskan dalam al-Qur'an surat at-Taubah : ayat 105

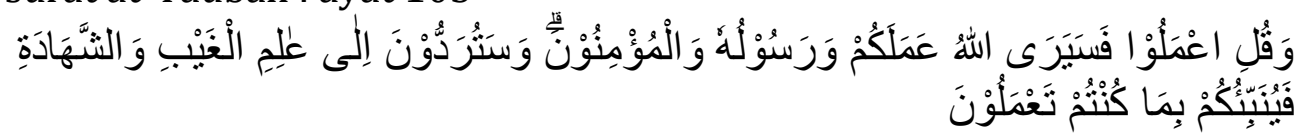

Artinya: "Dan Katakanlah: "Bekerjalah kamu, maka Allah akan melihat pekerjaanmu, begitu juga rasul-Nya serta orang-orang mukmin,dan kamu akan dikembalikan kepada (Allah) yang Mengetahui yang ghaib dan yang nyata, lalu diberitakan-Nya kepada kamu apa yang telah kamu kerjakan". 39

Hamka menjelaskan Allah menyuruh bekerja menurut bakat dan bawaan, juga menurut tenaga dan kemampuan. Ayat ini menjadi rangsangan yang hebat dari Allah, yaitu melarang malas dan

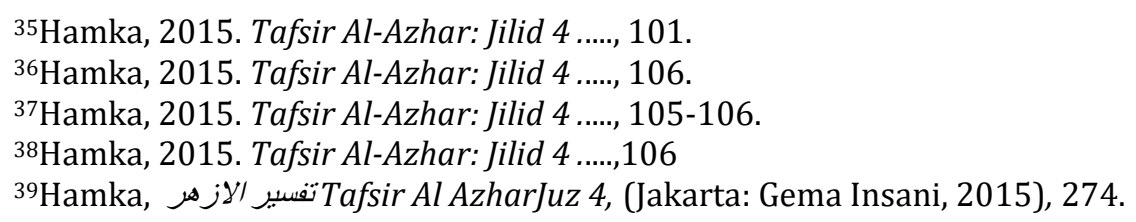


membuang-buang waktu. Mutu pekerjaan harus selalu ditingkatkan dan selalu memohon petunjuk dari Allah. ${ }^{40}$

Melakukan kegiatan wirausaha bagi seorang muslim tujuannya beribadah pada Allah SWT karena lebih tinggi derajat dan pahalanya. Sebab dalam shalat 5 waktu sudah berjanji, bahwa shalatku, ibadahku, hidupku, dan matiku adalah karena Allah SWT. Umat muslim menjalankan suatu usaha adalah dalam rangka ibadah kepada Allah. Demikian pula hasil yang diperoleh dalam berwirausaha akan dipergunakan kembali di jalan Allah. Bekerja adalah sebagian dari kewajiban hidup manusia yang harus ditunjukkan untuk beribadah kepada Allah SWT. dan juga memberi serta mengeluarkan infak dan zakat sesuai dengan aturan agama Islam. Sebagaimana Bukhari meriwayatkan hadits dari Miqdam ibn Ma'dikarib, Nabi Saw. Bersabda:

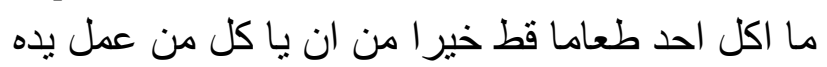

Artinya: Seseorang makan suatu makanan dari hasil usaha tangannya sendiri adalah yang terbaik. 41

c) Syarat-syarat Bekerja.

Persyaratan perniagaaan atau usaha agar tidak merugi, dijelaskan dalam al-Qur'an surat Faathir ayat 29.

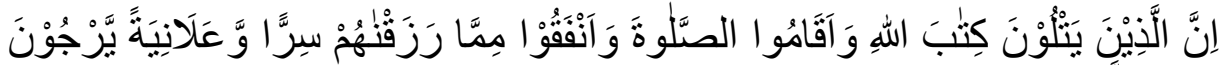

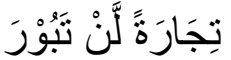

Artinya:"Sesungguhnya orang-orang yang selalu membaca kitab Allah dan melaksanakan shalat dan menginfakkan sebagaian dari rezeki yang Kami anugerahkan kepadanya dengan diam-diam dan terang-terangan, mereka itu mengharapkan perdagangan yang tidak akan merugi”. ${ }^{42}$

Ayat di atas memberikan tuntunan bagi orang yang ingin usaha atau perniagaan tidak merugi, harus memiliki 3 (tiga) persyaratan yaitu: selalu membaca al-Qur'an, mendirikan shalat dan mengeluarkan zakat. Melalui tiga syarat di atas, Allah akan menjamin bahwa perniagaan di dunia tidak akan merugi. Siapa saja yang berniaga dengan Allah, Allah akan memberikan keuntungan yang besar dengan lipatan sepuluh, tujuh ratus lipatan pahala, bahkan tidak dapat dihitung kelipatannya. Allah akan menyambut amalan hambanya yang didasari ikhlas karena Allah. ${ }^{43}$

${ }^{40}$ Hamka, 2015. Tafsir Al-Azhar: Jilid 4 ....., 282.

${ }^{41}$ Wajidi Sayadi, Op. Cit., 135.

42Hamka, 2015. Tafsir Al-Azhar: Jilid 7 ....., 369.

43Hamka, 2015. Tafsir Al-Azhar: Jilid 4 ....., 374-375. 
Maksud dengan membaca al-Qur'an adalah membaca dan memahami serta meresapi maknanya, sehingga menjadi tuntunan dalam kehidupan manusia termasuk dalam perniagaan atau perdagangan. Sedang dengan mendirikan shalat, manusia akan selalu berkomunikasi dengan Allah secara rutin dan jiwanya selalu berkomunikasi secara langsung dengan Allah. Syarat lain mengeluarkan zakat, melalui zakat dapat memperkukuh hubungan dengan masyarakat dan menjaga diri dari sifat bakhil yang sangat berbahaya bagi perkembangan jiwa manusia. Manusia yang memiliki kepribadian yang disebut di atas, akan mempunyai kekayaan jiwa yang selalu diridhoi Allah, selalu peduli dengan kehidupan orang lain dan selalu terkontrol setiap saat dalam pengawasan Allah. ${ }^{44}$ Oleh sebab itu pasti akan mendapat keberkahan dan keuntungan yang melimpah baik secara materi atau non materi di dunia dan akherat, termasuk dalam usahanya dalam perniagaan atau perdagangan apa pun di dunia ini.

d) Bekerja yang Tidak Melupakan Akherat.

Allah menjelaskan bahwa usaha yang benar di dunia tidak akan melupakan akherat, sebagaimana terdapat dalam al-Qur'an surat AnNuur ayat 37.

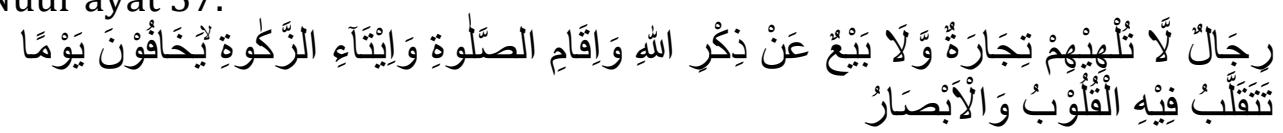

Artinya: "Yaitu orang-orang yang tidak dilalaikan oleh perdagangan dan jual beli, dari mengingat Allah dan mendirikan shalat dan mengeluarkan zakat. Mereka takut kepada hari ketika hati dan penglihatan menjadi guncang (hari kiamat)". ${ }^{45}$

Ciri-ciri orang-orang yang tidak terlalaikan dari perdagangan dan jual beli di dunia adalah selalu melatih jiwa mendekati Allah SWT melalui: mendirikan shalatm, mengeluarkan zakat, membebaskan dan melepaskan dari pengaruh benda, pangkat kebesaran dan kekayaan, jual beli dan untung rugi, tidak gentar atau takut terhadap perkisaran hari dan masa, tidak gentar melihat naik dan turun pasang zaman, serta penglihatannya tidak terpesona oleh warna warni yang palsu. Hamka menyebut orang yang disebut dalam ayat di atas adalah laki-laki sejati yang telah

${ }^{44}$ Hamka, 2015. Tafsir Al-Azhar: Jilid 4 .....,374

${ }^{45}$ Hamka, 2015. Tafsir Al-Azhar: Jilid 4 ....., 304. 
menyediakan dirinya untuk Allah SWT. dan telah mendapatkan cahaya Allah SWT. 46

\section{Nilai-nilai Kewirausahaan.}

Nilai-nilai kewirausahaan yang ditemukan dalam kajian tafsir al-Azhar karya Hamka meliputi:

a. Nilai Kreatif.

Nilai kreatif dalam kewirausahaan merupakan kecerdasan dalam menghasilkan hasil berbeda dari produk atau jasa, ditegaskan dalam al-Qur'an surat Al-Mulk ayat 15.

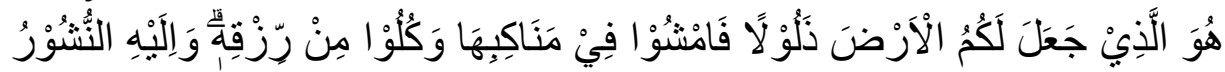

Artinya:"Dialah yang menjadikan bumi untuk kamu yang mudah dijelajahi, maka jelajahi lah di segala penjurunya dan makanlah sebagian dari rezeki-Nya. Dan hanya kepada-Nya kamu kembali setelah dibangkitkan”. ${ }^{47}$

Manusia dikirim ke bumi dengan segala kelengkapan hidup manusia. Maka tidak boleh bermalas-malasan dan menganggur. Oleh karena itu Allah memberikan kecerdasan kepada manusia, untuk dapat membuka rahasia yang tersembunyi di bumi ini. Sebab manusia telah ditaqdirkan Allah selalu ingin maju dan berubah. Kemajuan manusia dalam membongkar rahasia bumi tidak akan membawa kecemasan, tapi akan mendatangkan keberkahan dan kedamaian hidup di dunia dan di akherat. Orang yang memiliki kreatif dan kecerdasan akan memiliki sebuah pemikiran bahwa manusia dapat memperbaiki dan mengembalikan ruh kepada pangkalnya, agar rasa cinta tumbuh dan rasa kaku hilang, dengan mengikatkan diri manusia kepada Yang Maha Kuasa. ${ }^{48}$

b. Nilai Jujur.

Allah telah menegaskan tentang hasil usaha manusia selalu menghasilkan yang baik, hal merupakan nilai jujur sebagaimana dijelaskan dalam al-Qur'an surat al-Mukminun ayat 51.

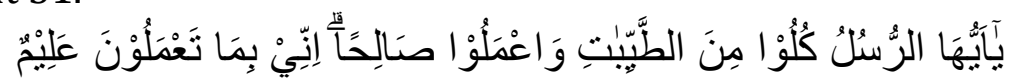

Artinya:"Wahai para rasul makanlah dari makanan yang baik-baik dan kerjakanlah kebajikan. Sungguh, Aku Maha Mengetahui apa yang kamu kerjakan". ${ }^{49}$

${ }^{46}$ Hamka, 2015. Tafsir Al-Azhar: Jilid 4 ....., 308.

${ }^{47}$ Hamka, 2015. Tafsir Al-Azhar: Jilid 9 ......, hlm. 247.

${ }^{48}$ Ibid., hlm. 249-250.

${ }^{49}$ Hamka, 2015. Tafsir Al-Azhar: Jilid 6 ......, 197. 
Hamka menyatakan jiwa yang bersih dan dapat mengendalikan orang lain adalah jiwa yang dapat mengendalikan diri sendiri, hal ini sangat berkaitan dengan sesuatu yang di makan dari hasil usahanya yang halal dan ini merupakan sifat jujur. ${ }^{50}$ Jadi maksud ayat di atas, bahwa wujud nilai jujur kewirausahaan adalah usaha seseorang yang menyatakan usaha yang bernilai halal, bersih dan baik, akan mendatangkan kebersihan jiwa dan akhirnya dapat mengendalikan diri sendiri, dan bahkan orang lain, serta berdaya guna dan berfaedah bagi sesama masyarakat. Manusia sebagai umatnya, senantiasa mengikuti jejak para nabi dan rasul Allah, dalam berbagai usaha di dunia sebagai pertanggungjawaban manusia pada dirinya yang telah beriman

Kebersihan, kehalalan dan kethayyiban makanan menjadi syarat untuk meraih derajat kedudukan manusia yang tinggi. Sebagaiman Sayyid Quthb menyampaikan makan dari perkara-perkara yang baik merupakan faktor yang dapat meninggikan kedudukan kemanusiaan, menyucikan baik lahir maupun jiwa, dan dapat menghubungkan ke kedudukan malaikat yang tinggi. ${ }^{51}$ Maksudnya bahwa manusia hidup tidak dituntut melepaskan sifat kemanusiaanya tapi yang dituntut adalah mengangkat kepada kedudukan yang tinggi dan mulia sesuai dengan kehendak Allah.

c. Nilai Inovatif.

Allah menjelaskan tentang nilai inovatif dalam bentuk usaha manusia sebagaimana dijelaskan dalam al-Qur'an surat al-Jumuah ayat 10, yang artinya : "Maka apabila shalat telah dilaksanakan, maka bertebaranlah kamu di bumi dan carilah karunia Allah dan ingatlah Allah banyak-banyak agar kamu beruntung". 52

Hamka menegaskan karunia Allah, ada di mana-mana, dan siapapun dapat meraihnya dengan proses yang inovatif dalam berusaha dan bekerja dengan sungguh-sungguh. Hasil inovasi sesuai ayat di atas, bentuk-bentuk karunia Allah dapat berupa: menggembala dan beternak, bertani dan berladang, berniaga dan jual beli, serta usaha-usala lain yang sifatnya halal.53

Dalam perkembangan zaman selalu diiringi dengan inovasi para pengusaha dengan bermacam-macam produk yang dijual baik barang, jasa dan lain-lain yang nilainya halal, contoh jual beli on line, persewaan motor dan mobil. Dalam hal inovasi usaha Hamka menambahkan dalam proses usaha apa pun, harus selalu ingat kepada Allah, sehingga dapat mengendalikan diri

${ }^{50}$ Hamka, 2015. Tafsir Al-Azhar: Jilid 6 ......,198.

${ }^{51}$ Quthb, Sayyid, 2016. تفسيد في ظلال القران (Jakarta: Gema Insan), 178.

52Hamka, تفسبر الازهر Tafsir Al Azhar Juz 9, (Jakarta: Gema Insani, 2015),128.

53Hamka, تفسير الازهر Tafsir Al Azhar Juz 9, (Jakarta: Gema Insani, 2015),143. 
sehingga tidak terperosok dalam perbuatan yang tidak diridhoi Allah yang merupakan keberuntungan dari apa yang diusahakan mendapat kehalalan dan berkah berkah Allah. Setengah ulama salaf berkata, siapa yang dapat berjual beli selepas Jum'at akan diberi berkah oleh Allah tujuh puluh kali. ${ }^{54}$

d. Nilai Tanggung Jawab.

Allah menegaskan tentang waktu untuk penghidupan sebagai nilai tanggung jawab manusia untuk bekerja sebagaimana dijelaskan dalam alQur'an surat an-Naba ayat 11.

Artinya:"Dan Kami jadikan siang untuk mencari penghidupan". 55

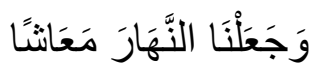

Hamka menegaskan ma'isyah adalah penghidupan dan waktunya di siang hari dari pagi sampai sore/bergantinya malam. Setelah badan dan jiwa menjadi segar, manusia mulai bekerja dan melakukan kegiatan di atas bumi yang terbentang, untuk mencari perbekalan untuk hidup, mencari rizki, mencari makan dan minum. ${ }^{56}$ Manusia mempunyai tugas dan tanggung jawab untuk mencari nafkah dari pagi sampai siang atau sore hari. Hasil dari usaha yang dikerjakan dalam seharian diperuntukkan keluarga.

e. Nilai Realistis.

Allah swt menjelaskan tentang hasil usaha manusia merupakan anugerah Allah swt yang realistis, yang terdapat dalam al-Qur'an surat al-Qashash ayat 77.

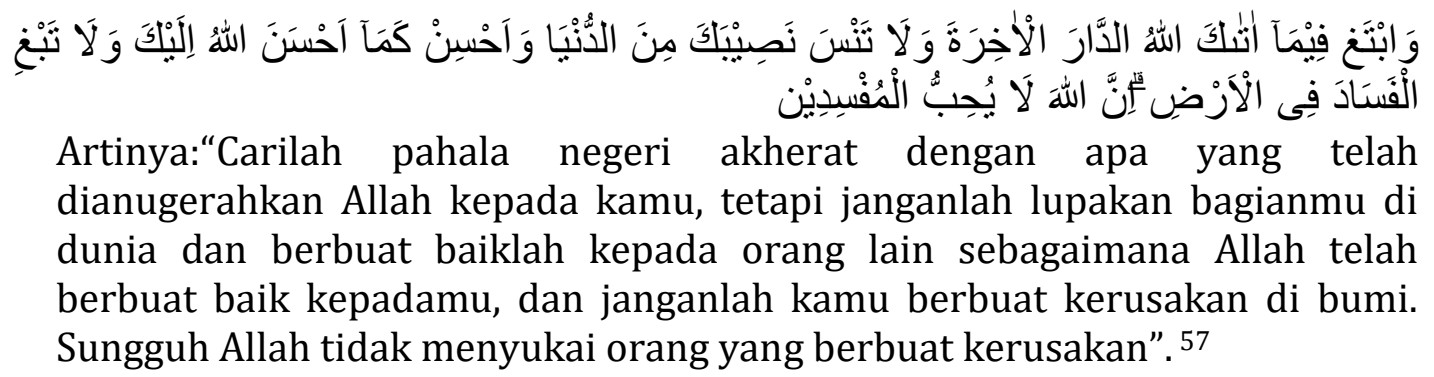

Hasil usaha yang baik di dunia harus dimanfaatkan dengan sebaik-baiknya, untuk kemanfaatan kehidupan besok di akhirat, melalui menafkahkan sebagian rizki untuk jalan kebaikan. Lebih tegas lagi bahwa bagian di dunia yaitu harta yang halal. Karena hakikatnya dalam hasil usaha seseorang secara realistis, akan berkah bila diinfakkan sebagai kepada yang berhak menerimanya. Hamka

54Hamka, تفسير الازهرTafsir Al Azhar Juz 9, (Jakarta: Gema Insani, 2015)

55Hamka, تفسير الازهر Tafsir Al Azhar Juz 9, (Jakarta: Gema Insani, 2015). 468.

56Hamka, تفسبر الازهر Tafsir Al Azhar Juz 9, (Jakarta: Gema Insani, 2015). 469.

${ }^{57}$ Hamka, 2015. Tafsir Al-Azhar: Jilid 6 ....., 631. 
mensyaratkan dalam penggunaan harta atau hasil usaha, yaitu: tidak boleh merugikan orang lain, yang akan memutuskan hubungan silaturrahmi, menganiaya orang lain, mengganggu keamanan, menyakiti sesama manusia, membuat onar, menipu dan mengecoh, serta mencari keuntungan semata untuk diri sendiri, dengan melupakan hak-hak orang lain. ${ }^{58}$

f. Nilai Kerja Sama.

Pada hakekatnya semua harta yang di bumi ini adalah miliki bersama, sebagaimana Alah berfirman dalam al-Quran surat an-Nisa' ayat 29.

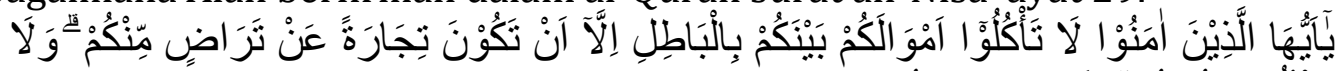

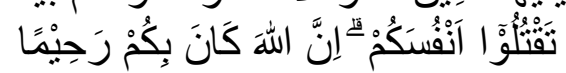

Artinya:"Wahai orang-orang yang beriman! Janganlah kamu memakan harta sesama kamu dengan jalan batil, kecuali dalam perdagangan yang berlaku atas dasar suka sama suka di antara kamu. Dan janganlah kamu membunuh dirimu. Sungguh Allah Maha Penyayang kepada kamu". 59

Hakekatnya kekayaan adalah kepunyaan milik bersama, sebab dalam karta kekayaan yang dimilikinya selalu ada hak orang lain, yang wajib dikeluarkan pada waktunya. Dalam hal ini perlu ada kerja sama antara orang kaya dan orang misikin. Artinya hasil kekayaan ada sebagai yang harus dikeluarkan sebagai zakat atau zakat yang diserahkan kepada yang berhak menerimanya. Kekayaan yang dimiliki oleh manusia dihasilkan dari perniagaan atau perdagangan yang benar yaitu: segala jual beli, tukar menukar, gaji menggaji, sewa menyewa, impor dan ekspor, upah mengupah dan semua perniagaan yang menimbulkan peredaran harta benda. 60

Maksud lain bahwa harta kekayaan milik bersama mengandung arti, perlu dikelola dalam bentuk kerja sama melalui suatu badan tertentu, seperti lembaga zakat. Hasil usaha dikelola oleh lembaga tertentu dan penyaluran secara profesional kepada yang berhak menerima. Sebagai tanda syukur kepada Allah orang harus mengeluarkan zakat, sedekah dan berkurban untuk kepentingan masyarakat. Dan juga perlu ditegaskan bahwa orang yang tidak mengeluarkan zakat termasuk memakan harta dengan batil, dan bahkan dapat menimbulkan iri hati dan kebencian orang miskin.61

\section{Relevansi dengan Materi Mata Kuliah Kewirausahaan.}

${ }^{58} \mathrm{Hamka}$, 2015. Tafsir Al-Azhar: Jilid 6 ......, 634.

${ }^{59}$ Hamka, 2015. Tafsir Al-Azhar: Jilid 2 ....., 261.

${ }^{60}$ Hamka, 2015. Tafsir Al-Azhar: Jilid 2 ....., 262.

${ }^{61}$ Hamka, 2015. Tafsir Al-Azhar: Jilid 2 ....., 263. 
Penulis dapat menjelaskan tentang relevansinya dengan materi mata kuliah pendidikan kewirausahaan di STAI Masjid Syuhada Yogyakarta. Setelah penulis menelaah konsep kewirausahaan dalam tafsir al-Azhar terdapat relevansinya dengan materi mata kuliah kewirausahaan di STAI Masjid Syuhada Yogyakarta.

Konsep kewirausahaan menurut Hamka mengajak pelaku bisnis kembali kepada dasar al-Quran dan as-Sunnah sebagai pedoman dalam menjalankan berbagai bentuk usaha di dunia. Hamka juga memberikan konsep nilai-nilai kewirausahaan sebagaimana telah dipraktekkan oleh Rasulullah Saw dalam perniagaannya. Nilai-nilai yang yang terdapat dalam tafsir al-Azhar meliputi nilai kreatif, jujur, inovatif, tanggung jawab, realistis dan kerja sama. Begitu juga penulis telah menelaah silabus mata kuliah kewirausahaan di STAI Masjid Syuhada Yogyakarta, telah diajarkan kepada para mahasiswa tentang bisnis muslim: bisnis model Rasulullah saw, prinsip-prinsip etos kerja dalam Islam, sifat-sifat kepemimpinan, keunggulan sikap mental, pengetahuan praktek dan skill. Materi-materi yang mengandung relevansi ditegaskan dalam tabel di bawah ini.

Tabel 6.

Relevansi Konsep Kewirausahaan dengan Materi Mata Kuliah Kewirausahaan

\begin{tabular}{|c|l|l|}
\hline No & Konsep Kewirausahaan & Materi Kewirausahaan \\
\hline 1 & $\begin{array}{l}\text { Konsep dasar bekerja, tujuan bekerja } \\
\text { dan syarat-syaratnya }\end{array}$ & Prinsip-prinsip etos kerja dalam Islam \\
\hline 2 & Bekerja yang tidak melupakan akherat & Bisnis Muslim: Bisnis Model Rasulullah Saw \\
\hline 3 & Nilai tanggung jawab dan kerja sama & Sifat-sifat kepemimpinan \\
\hline 4 & Nilai kreatif, jujur, inovatif, dan realistis & $\begin{array}{l}\text { Keunggulan sikap mental, pengetahuan } \\
\text { praktek dan ketrampilan }\end{array}$ \\
\hline
\end{tabular}

Sumber: Konsep kewirausahaan dalam tafsir al-Azhar karya Hamka dan rencana pembelajaran semester mata kuliah kewirausahaan STAI Masjid Syuhada Yogyakarta.

Konsep kewirausahaan yang ditemukan dalam tafsir al-Azhar secara dataran teori sudah sesuai syar'i, tapi masih perlu dioperasioanlkan secara konkrit dalam kehidupan manusia. Konsep kewirausahaan meliputi dalam dua aspek, pertama konsep dasar meliputi dasar bekerja, tujuan bekerja, syarat-syaratnya dan bekerja yang tidak melupakan akherat. Kedua mengandung nilai kreatif, jujur, iniovatif, realistuis, tanggung jawab dan kerja sama. Sedang letak relevansi dapat diketahui bahwa konsep dasar dan nilai kewirausahaan yang terdapat dalam tafsir al-Azhar, telah di buat dalam struktur rencana pembelajaran semester mata kuliah kewirausahaan di STAI Masjid Syuhada Yogyakarta. Materi-materi yang diterapkan dalam RPS STAIMS Yogyakarta meliputi prinsip-prinsip etos kerja dalam Islam, 
bisnis muslim model Rasulullah Saw, sifat-sifat kepemimpinan, keunggulan sikap mental, pengetahuan praktek dan ketrampilan.

\section{KESIMPULAN}

Konsep dasar kewirausahaan adalah dasar bekerja, tujuan bekerja adalah ibadah, syarat-syarat bekerja dan bekerja tidak melupakan akherat. Nilai-nilai kewirausahaan dalam tafsir al-Azhar adalah nilai kreatif, jujur, inovatif, tanggung jawab, realistis dan kerja sama. Adanya relevansi antara konsep kewirausahaan dalam tafsir al-Azhar dengan materi mata kuliah kewirausahaan yang diajarkan kepada mahasiswa di STAI Masjid Syuhada Yogyakarta. Intinya mengajak pelaku usaha kembali kepada dasar al-Quran dan as-Sunnah sebagai pedoman dalam menjalankan berbagai bentuk usahanya di dunia. Dalam proses pelaksanaan usahanya perlu didukung dengan nilai-nilai kewirausahaan yang tertanam dalam dirinya.

\section{DAFTAR PUSTAKA}

Adeng Muchtar Ghazali. 2005. Ilmu Studi Agama, Bandung : Pustaka, Setia.

Afzalurrahman. 1997. Muhammad sebagai Seorang Pedagang, Jakarta: Yayasan Swarna Bhumy.

Agus Wibowo. 2011. Pendidikan Kewirausahaan, Yogyakarta: Pustaka Pelajar.

Agus Arwani. 2017. Konsep Akad (Transaksi) Dalam Islam, Januari.

Andri Soemitra. 2015. Kewirausahaan Berbasis Syariah, Medan: CV. Manhaji dengan Fakultas Syariah dan Hukum UIN Sumatera Utara.

Azyumardi Azra. 1999. Pendidikan Islam Tradisi dan Modernisasi, Jakarta: Logos.

Bahri. 2018. Kewirausahaan Islam: Penerapan Konsep Berwirausaha dan Bertransaksi Syariah dengan Metode Dimensi Vertikal (Hablumminallah) dan Dimensi Horizontal(Hablumminannas), Maro Jurnal Ekonomi Syariah dan Bisnis,Vol. 1. No.2 November.

Daniel A. Kuncoro. 2009. 101 Tips Sukses Bisnis, Yogyakarta: In Azna Books.

Devi Anggita. 2017. Enterpreneurship Dalam Perspektif Ekonomi Islam (Studi Pada Pengusaha Rumah Makan Padang Putri Minang), Makassar: Fakultas Ekonomi Dan Bisnis Islam Universitas Islam Negeri Alauddin.

Eko Agus Alfianto. tt. Kewirausahaan: Sebuah Kajian Pengabdian Kepada Masyarakat. Dalam Jurnal Universitas Yudharta Pasuruan.

Fadhlurrahman. 2017. Tesis: "Nilai-nilai Pendidikan Kewirausahaan dalam Al-Quran di Muhammadiayah Boarding School Purworejo", Pascasarjana UIN Sunan Kalijaga Yogyakarta.

Fauzan. 2014. Hubungan Religiusitas dan Kewirausahaan: Sebuah Kajian Empiris Dalam Perspektif Islam, MODERNISASI, Vol. 10, No. 2, Juni. 
Haji Abdul. tt. Dan Aku pun Masukkan dalam Daftarmu.

Hamka. 2002. Di Bawah Lindungan Ka'bah, Shah Alam: Pustaka. .2015. تفسير الازهر Tafsir Al AzharJuz I, Jakarta: Gema Insani. 2015. تفسير الازهر Tafsir Al AzharJuz 2, Jakarta: Gema Insani. .2015. تفسير الازهر Tafsir Al AzharJuz 4, Jakarta: Gema Insani. .2015. تفسير الازهر Tafsir Al AzharJuz 6, Jakarta: Gema Insani. .2015. تفسير الازهر Tafsir Al AzharJuz 7, Jakarta: Gema Insani. 2015. تفسير الازهر Tafsir Al Azhar Juz 9, Jakarta: Gema Insani.

Hasan Langgulung. 2001. Pendidikan Islam, Jakarta: PT. Al Husna Zikra.

Hasan Langgulung.2005. Beberapa Pemikiran tentang Pendidikan Islam, Bandung: AlMa'arif.

Irham Haidar. 2017. Kewirausahaan Dalam Perspektif Hadis, Semarang: Fakultas Ushuluddin Dan Humaniora Universitas Agama Islam Negeri Walisongo.

J. Winardi. 2003. Entrepreneur dan Entrepreneurship, Jakarta: Prenadamedia Group. J.J. Fox. 2008. Bisa Kaya dari Bisnis \&Usaha Kecil, Yogyakarta: Think.

Khairuddin Aljunied. 2016. Reorienting Sufism: Hamka an Islamic Mysticism in the Malay World, Indonesia 101.

Koentjaraningrat. 1983. Metode Penelitian Masyarakat, Jakarta : Gramedia.

Komaruddin Hidayat. 2015. Psikologi Kebahagiaan, Jakarta: Noura Books.

Mohammad Damami. 2000. Tasawuf Positif (dalam pemikiran HAMKA), Yogyakarta: Fajar Pustaka Baru.

Muh. Hasbi Ash-Shiddieqy. 2016. Al-Quranul Majid An-Nur, Semarang: Pustaka Rizki Putra.

Muhammad Mujadded Hidayatullah. 2016. Mahasiswa Fakulktas Ushuluddin Universitas Negeri Walisongo, Skripsi dengan Judul Tafsir Ayat-ayat Wirausaha di Pesantren Entrepreneur Tegalrejo Magelang.

Muhammad Sa'roni. 2012. "Mendidik \& Melatih Entrepreneur Muda, Yogyakarta: ArRuzz Media.

Muzayyin Arifin. 2009. Filsafat Pendidikan Islam, Jakarta: PT Bumi Aksara.

Mohammad Ali \& Mohammad Asori. 2014. Psikologi Remaja Perkembangan Peserta Didik, Jakarta: PT. Bumi Aksara.

M. Quraisy Shihab. 1994. Membumikan Al Quran : Fungsi dan Peran Wahyu dalam Kehidupan Masyarakat Bandung: Mizan.

Nunu Burhanuddin. 2016. Konstruksi Pendidikan Integratif Menurut Hamka, Jurnal Educative: Journal of Educational Studies 1, no. 1. 
Nur Hamim. 2009. Manusia dan pendidikan elaborasi pemikiran HAMKA, Sidoarjo: Qisthos.

Rahmawati. 2011. Dinamika Akad Dalam Transaksi Ekonomi Syariah, Al-Iqtishad, Vol. 3, No. 1, Januari.

Sugiyono. 2015. Cara Mudah Menyusun Skripsi, Tesis dan Disertasi, Bandung : Alfabeta.

Suharsimi Arikunto. 2016. Prosedur Penelitian Suatu Pendekatan Praktek, Jakarta : : Rineka Cipta.

Suharyanta. 2012. Administrasi Pendidikan Islam, Yogyakarta: Idea Press.

Soejono dan Abdurrohman. 1999. Metode Penelitian Suatu Pemikiran Dan Penerapan, Jakarta: PT Rineka Cipta.

Suryana. 2009. Kewirausahaan, Pedoman Praktis Kiat dan Proses Menuju Sukses, Jakarta: Salemba Empat.

Suti'ah Muhaimin dan Nur Ali. 2002. Paradigma Pendidikan Islam, Bandung: PT Remaja Rosdakarya.

Sri Wigati. tt. Kewirausahaan Islam (Aplikasi dan Teori), Buku Perkuliahan S1, Prodi Hukum Ekonomi Syariah (Muamalah), Fakultas Syari'ah dan Hukum, UIN Sunan Ampel Surabaya.

Tim Penyusun. 2018. Pedoman Penulisan Skripsi, Yogyakarta: STAIMS Press.

Wajidi Sayadi. 2011. Hadis Tarbawi, Jakarta: Pustaka Firdaus.

Quthb, Sayyid. 2016. تفسير في ظلال القران, Jakarta: Gema Insan.

Yana Hendayana, Dini Lisnawati, Amir Machmud. 2017. Kewirausahaan Berbasis Syariah, Bandung: Manggu Makmur Tanjung Lestari.

Zahid Mubarok. 2017. Konsep Pendidikan Wirausaha dan Kemandirian bagi Anak Panti Asuhan, Jurnal Ta'dibuna Jurnal Pendidikan Islam, Universitas Ibnu Khaldun Bogor. Volume 6, nomor 1. 